\title{
Paideusis
}

\section{"Thinking Again: Education after Postmodernism" (Nigel Blake, Paul Smeyers, Richard Smith, and Paul Standish)}

\section{Donovan Plumb}

Volume 12, Number 2, 1999

URI: https://id.erudit.org/iderudit/1073090ar

DOI: https://doi.org/10.7202/1073090ar

See table of contents

Publisher(s)

Canadian Philosophy of Education Society

ISSN

0838-4517 (print)

1916-0348 (digital)

Explore this journal

Cite this review

Plumb, D. (1999). Review of ["Thinking Again: Education after Postmodernism" (Nigel Blake, Paul Smeyers, Richard Smith, and Paul Standish)]. Paideusis, 12(2), 57-59. https://doi.org/10.7202/1073090ar 


\section{Book Review}

\section{Nigel Blake, Paul Smeyers, Richard Smith, and Paul Standish (1998). Thinking Again: Education After Postmodernism. Westport, CT: Bergin and Garvey. 202 pages.}

From the embattled world of the old federal state of Yugoslavia, Slovenian philosopher, Slavoj Zizek offers instructive, politically incisive words of advice. To truly understand someone's work, he suggests, it is important to ask "not what he or she asserts, but what is the image of the enemy that the work implies?"1 At first glance, the "enemy" of Thinking Again seems to be those forces who strive to impose "conditions of performativity" on schools and teachers. From this view, "Thinking Again"' can be read as a mustering of theoretical defenses: we should reconsider French poststructuralist and postfoundationalist philosophers like Jacques Derrida, Michel Foucault, Jacques Lacan, and Jean-Francois Lyotard as they offer powerful strategies for deconstructing the foundations of managerialism. A deeper look at the text, however, reveals another, less overtly hurtful, but more pernicious enemy this time-an enemy right within the ranks. "Thinking Again," from this view, contests those educational philosophers who preemptively either dismiss or celebrate postmodernism as a relativistic and nihilistic theoretical perspective. Faced with the hard work of living a "community of difference," this enemy wants us to spurn any sustained dialogue across differences in favor of a retreat either to foundationalism or to radical relativism. The book's engagement with this latter enemy is estimable: the authors do a commendable job defending the difficult terrain of dialogical democracy. The fault of Thinking Again however, is that, in turning us to face the philosopher foe, it turns us away from larger, more impressive dangers that lurk in postmodern times.

From the outset, the authors of Thinking Again assert the multivocality of their discourse. This text, they observe, does not form a single piece. Rather, it is a series of twelve forays into the world of postmoderist thought. Still, the book does hang together. The twelve chapters, bracketed by a "Retrospect" and a "Prospect," do not display the fragmented, iconic wildness of contemporary texts on the Internet or of many books on media culture. It does not have any cartoons, images, or weird fonts. The book makes sense without leaving many loose ends at all. It is rational, not rhetorical; argumentative, not iconic. Given that four authors wrote Thinking Again, what is remarkable is its unity, not its diversity.

For instance, a theme that runs like a highway throughout the book is that negative reactions to poststructuralist and postfoundationalist discourses are based on profound misconceptions that stem from an underlying fear of living without secure foundations. In the first chapter, "Poststructuralism and the Spectre of Relativism," the authors illuminate how, while poststructuralists like Derrida acknowledge the indeterminacy and multiplicity of discourse, they should not be considered radically relativistic. They support neither a subjective relativism, where "what is 'knowledge for you' and 'what is knowledge for me' cannot be the same," 2 nor a linguistic relativism, where the truths afforded by our language and the truths afforded by their language need not be the same. In the second chapter, "Foundations Demolished, Sovereigns Deposed,"they sug- 
gest that the poststructuralist deconstruction of the metanarratives of modernity does not abandon us to relativism. The knee-jerk reaction of many educationists to the fragmentations of postmodernity, the retreat to a nostalgic foundationalism that denies difference and the multiplicity of discourse, reflects their failure to appreciate the ways knowledge and morality emerge through discourse: "[U]nless and until we are bound into this tight skein of linguistic bonds, which extend vertically through history and tradition no less than horizontally through affinity and society, then we cannot think propositionally at all, far less think morally.", Educators resist poststructuralism precisely because, in highlighting the nature of discourse, it illuminates the social power subtending the truths these educators want to assume.

Other chapters explore branches of this more general theme. The third, fifth and eighth chapters, for instance, carefully consider the implications of poststructuralism for our conceptions of identity, morality, and desire. The last of these three chapters, "The Responsibility of Desire," is particularly insightful. It offers a lucid summary of Jacque Lacan's analysis of desire and subject formation and draws out clear and practical implications of his work for educators. It observes, for instance, that, because human subjects are formed in the crucible of the symbolic order and because this order is comprised of a plurality of often contradictory discourses, it is impossible for a subject to know fully who he or she is. Instrumental educational systems work with the mistaken view that transparency is possible: it is possible for a subject to know him or herself and his or her world. As the authors explain in this chapter, though, "the Lacanian position? challenges several pictures that are deficient and that held us captive, not the least that we know what we really want." 4 The idea that educators can help the subject fill in the gaps in his or her understanding is fundamentally misdirected. The contradictions and heterogeneity of the symbolic order that underlies subject formation always leaves a residual lack, no matter what is leamed.

Other chapters of Thinking Again reveal the capacity of poststructuralism to shed insight into varied educational issues. Chapter Four, "Literacy Under the Microscope," details the "cultural and educational divide" between those who assert objectives, standards, and measures of literacy (a foundationalist perspective) and those who "relish the constructedness of texts and their multilayered ironies." 5 Chapter Six, "Giving Someone a Lesson," critiques the instrumental determinism of competency-based or outcomes-based education.

These chapters interweave with others to engender a rich and varied tapestry of insight. The authors do indeed demonstrate the critical relevance of poststructuralist and postfoundationalist discourses to education. This is no small task. Theorists like Derrida, Foucault, and Lacan are difficult to understand or discuss. They do not line up their formulations in neat rows; rather, they delight in the verdancy of language. The authors of Thinking Again must be commended on their interpretive powers. They offer lucid and accurate depictions of the main tenets of poststructuralism without draining it altogether of its mysterious vitality. This is a book not quickly read: it beckons return and reconsideration. With each return, another lack and another desire appears. It is not an account that leaves us mystified, but neither is it a book that spares us the difficult task of thinking again. 
Most importantly, though, the book does very well highlighting the current need to protect complex processes of dialogical learning from those who wish to reinstate an uncontestable, foundationalist, and instrumental form of education. At the conclusion of Chapter Nine, "Folly, Words, Wigs, Rags," the authors contend that, "[w]e need a keen eye for wigs, for the operations of power and the new (dis)guises which perfomativity wears, and we need to learn to move freely again among the rich plurality of rags, of language and forms of language. That very plurality fragments power, and diminishes its effectiveness."

This would be all well and good if modernity still reigned. In a transformed world, however, this admonition and the entire premise of poststructuralism and of Thinking Again are in danger of losing their purchase. Zizek, for example, is skeptical. He contends that the foundationalist and the fundamentalist are not the enemy today. Social domination now is affected through global, high-tech financial and administrative systems that thrive on social and cultural fragmentation: "[T]he whole late Foucauldian idea of multiple identities and an aesthetics of existence ... simply describes the conceptual structure of late capitalist subjectivity." The biggest difficulty with this book is that, in sticking to poststructuralism, Thinking Again binds itself to a theoretical point of view that may simply end up simply supporting today's forms of domination. Sure, dialogue across differences is great. Let's go for it. But, like Zizek, we also need to keep a keen eye on the forces of globalization that, by dint of their growing capacity to maneuver in ragged social and cultural environments, seem to be able to elude our every effort to resist.

\section{Notes}

1 S. Zizek (1996. “Lacan in Slovenia: An interview of Slavoj Zizek," in P. Osborn (Ed.), A critical sense: Interviews with intellectuals (New York: Routledge), p. 40.

2 Thinking Again, p. 12.

3 Ibid., p. 32.

${ }^{4}$ Ibid., p. 129.

5 Ibid., p. 49.

Reviewed by Donovan Plumb, Mount Saint Vincent University 